\title{
Mangupa;
}

\section{An Oral Tradition of Angkola Community}

\author{
Yusni Khairul Amri \\ Muhammadiyah University of North Sumatra (UMSU), Medan, Indonesia
}

Email; amri_lubis@ymail.com

\begin{abstract}
The oral traditions of indigenous communities Angkola mangupa belief to be efforts to restore stamina to the body (paulak tondi tu badan) to seek blessings from Allah, the Almighty God, to be safe, healthy, and prosperous in life. Mangupa levels adjusted corresponding to pangupa materials such as buffalo, goats, chickens, and eggs, then given advice mangupa (hata pangupa; hata upah-upah) submitted by traditional leaders. The analysis results of mangupa found the local knowledge values such as: a) the human relationship with God, b) the meaning of human life, $c$ ) the human relationship with the natural surroundings, d) the human relationship with time, e) the behavior to be industrious and enterprising, thrifty, and religious, to get along peacefully with each other; f) the aesthetic value of humility, customary of politeness, $g$ ) the expectation that the marriage will be the marriage of a lifetime; $h$ ) The value and philosophical significance of indigenous material derived pangupa animals, plants, and derived from nature; $i$ ) The bride and groom who have not through a traditional ceremonies (maradat) retains the customary effect throughout the traditional debt to be paid until they have the means.
\end{abstract}

Keywords: mangupa, local wisdom; literature; society

\section{INTRODUCTION}

Reality phenomenon found in the community, the perpetrators of indigenous elderly is dwindling, the process of inheritance naturally did not go as expected, the younger generation is 
not interested in doing customary activities, tedious time consuming ceremonial, indigenous language recurrent and over the times, the ceremony began to be simplified, because of financial factor (Amri, 2011:212). Based on this fact, efforts to maintaining tradition as tradition and as a source of knowledge of the present and future needs assessment of inheritance system, presenting indigenous Angkola as one source of knowledge to shape cultural identity of Angkola. Therefore it is necessary to manage the traditions by means of protection, preservation, and cultural revitalization as a tradition that needs assessment of the positive effects that have been keeping the traditional order in indigenous Angkola community.

The phenomenon that occurs lately, when the wealth of the nation's intangible claimed by our neighbor nation as their own, then we were shocked and 'enraged' the claim of the wealth of non-objects that was indeed belonging to our nation's culture. Meanwhile we as a legitimate owner of the traditions and customs and traditions of not an object heritage, customs and traditions considered it as an item that does not have values and benefits. Indigenous traditional as an ancestral tradition should not be viewed as such, where Angkola's custom and tradition should be seen as antiques and be preserved, ancient, frozen, outdated, which came from the past and have never been 'allowed' to change and glorified and perpetuated. The views of modern humans, tradition has always associated as outdated, old-fashioned, from that standpoint, it is a tradition to be abandoned if it wants to be considered modern (M. Ridwan Lubis, 2013). Viewpoint like this is wrong, merely historical relics that looked like: temples, statues, Ulos, bagasse Godang, musical instruments Gordang, gorga, single stick panaluan and others remain preserved. But ceremonies, martahi, marungut-ungut, marpege-pege, onangonang, ancestral traditions and rituals as intangible heritage.

\section{LITERATURE REVIEW}

This study takes the research object ceremony mangupa on indigenous Angkola community. The analysis is done from the words of the oral tradition mangupa under the perspective of linguistics as an umbrella science that was involved, and focus on antropolinguistik as an entrance (entry point) assessment, to see the meaning studied with the 
concept of semiotic theory. Smith (1846-1894) and to determine the oral tradition Folley worn theory Perspectives (1988), the oral tradition Ong (2007:37-56), Finnegan (1992:151). Toll and prudentia (1995:2) in Hoed (2008:184), Mangupa ceremony or upah-upah according Nalobi (1998:51) is one of the traditional ceremonies in Angkola, Mandailing, Southeren Tapanuli, Padang Lawas, North Padang Lawas. Local knowledge, as knowledge acquired by various strategies carried out for generations embodied as local knowledge in answering peroalan social life is often referred to as "local wisdom" or local knowledge "local knowledge" or local intelligence "local genious". According Avonina (2006) local wisdom that everything associated with traditional forms as a by certain cultures. Local wisdom gained in interacting with indigenous communities thus create peace sense of ease in the interaction with the interaction obtained good values, so as to create decent personality as a mirror traditional values regularly. This is confirmed by Rahyono (2009: 4-11) wisdom will produce the values and norms that sublime for the sake of living together. The assessment of the tradition mangupa will better appreciate the value of local knowledge that is structured to optimize cultural identity, which is an identity / personality of the nation's culture that led to a nation is able to absorb and process the cultural area corresponding character and cultural identities that have been going on for generations.

\section{METHODOLOGY}

The approach used in this study is a qualitative descriptive approach, using the descriptive method descriptive and explanatory adequacy framework based on the model. Developed by Watts. This research was conducted in the city of Padang Sidimpuan located at $432 \mathrm{~km}$ from Medan, North Sumatra, Indonesia which was located at Jalan Sudirman Gang PUD Padang Sidimpuan, Sadabuan North, North Sumatra Province. Data retrieval of customary marriage ceremony nagodang dated on 18-19 October 2014. The primary data source is the mangupa traditional ceremony research of Angkola community and the secondary data are from key informants, traditional leaders, indigenous practitioners and indigenous king with structured and unstructured interviews. The main data sources in qualitative research are the words and 
actions and the rest are additional data such as documents and others. The process of analyzing and organizing data into a pattern, categorize in order to become a basic description, so that it can be categorized into a working hypothesis, using the descriptive method done a thorough analysis and interpretation of the data. The steps to be taken in this research: describing the performance, analyzing the texts, contexts, context, and find the value of local knowledge of indigenous oral traditions mangupa of Angkola community.

\section{DISCUSSION}

\subsection{Mangupa with the contents to Say Praise to God Almighty}

Sentence optative/ desideratif as a sentence of hope is a sentence prayer so desires, ideals, hopes can be realized, the text mangupa mentioned: "... loput sadarion, hopefully blessed by God na markuasai ... it means: tired you start from yesterday to today, even so all you are doing hopefully blessed by God Almighty ... "

Mangupa text contents as the embodiment of confidence to his Creator with a prayer on the text mangupa on pangupa text: "... on a black rather than ambiguous-emphasized no, not us means comparing Nope, in mandoa tu Lord in prayer mangido Artina on the mangido God tu Namarkuasoi on as a symbol sasudena on ... it means: ask God Almighty, this (ceremony mangupa) that does not mean we are to double (God) ... no, not us collate the appeal ... is not, in praying to God in prayer requests God Almighty, these are all just as a symbol ... "the use pangupa devices consisting of various types of animals, will give rise to different meanings and invited guests who are not indigenous communities. The ceremony mangupa use offerings or the like which is believed to be a belief other than the Almighty, this is due.

\subsection{Mangupa which contained prayers to be healthy and Greetings}

Mangupa customary delivered by mothers at the ceremony mangupa to the child and the child in law show the love of parents to children on the text: "... hape madung tarpayak, payakon holong ni son holong ni ina ..." sentence means mangupa the "... which is already located, putting love dear child and maternal love ... "the sentence delivered mangupa mother to child is affirmed also by Anak Boru when opening pangupa material with the sentence:" ... a 
black ma sude mandokkon horas na diangan are delivered saut sincere wishful, horas ... horas..horas ... " means: "... all we say horas, in order to achieve what we aspire horas..horas..horas ..."

\subsection{Mangupa contents that Rukun Life and Peace (Being sakinah Family)}

Advice for householder's life are delivered by all traditional leaders Dalihan na tolu at a ceremony mangupa customary of Angkola community in order to live in harmony and peace (being in a harmonious family) can be categorized three parts: 1) advice to use the figurative phrases, 2) advice to use straightforward sentences, 3) advice to use a concrete example of life sentences, based on that text mangupa mentioned in the text mangupa below:

\section{a. Mangupa That Contains Advice in order to live Peacefully (Being in Sakinah Family) by Using Allegories Sentences}

The contents of the talks delivered at conveying words of advice in order to live in harmony and peace in households with figurative language in the tradition of mangupa indigenous of Angkola community such as: “... syukur ma nian seia sekata songon siala sampagul nina, rap tu jae rap tu julu..." which means: thank God they are in agreement as siala sampagul who are always together everywhere. Advice submitted using figurative sampagul siala fruit that tastes sour fruit that is shaped in the form of bunches sturdy enough for they are united. Sentence advice given by grandmothers (female), "... a) happisang repeated twice mardakka ... ta pa Bahat prayer songoni na hudokkanon Pahompu on ... b) sakali sampur happisang repeated twice mardakka on marduppang aso tarsambung tu jae dohot tu Julu ... "Which means: ... a) bananas cannot bear fruits twice ... b) banana tree doesn't bear fruits twice, be smart to have a family. It was seen on mangupa text, "... Maen, marsiahaan Hamu da Maen ..." can mean a) be smart to insert yourself to your husband, b) be smart to serve your husband, c) mutual love, by eliminating childish behavior. d) be smart in inserting yourselves to your husband extended family it was confirmed by the following sentence: "... the other ma Adong, Pade tu Edamu, Maen ..." Another ma sentence that also uses figurative language winged so do not behave not in accordance of the traditional order and behave yourself. 
b. Mangupa which contained advice for sharing a Peaceful Life (Being in Sakinah Family) Using the straight forward sentences

In mangupa text using simple sentences advice on sentences like: 1.Kadang kadang ributma, rebut ayahku bia dokkonon mada, 2. karas inang nai hum sada doi, de mada karas ia, ho pe do, 3. get mulak do pe bia do oppui songgakon lek oppui, yang artinya: 1) Sometimes noisy, my father ask what happened, 2) His mother says loudly, if she hard so you too! 3. Want to go home again, how your mother, crying your mother,

In the above sentence is addressed to children and parents (male) because the sentence that advice aimed to a loving mother to her child, especially the child is an only child (sakkibung) so that the love of parents to children is definitely more, so the interference from the mother to the child's family and the child' in law is higher, the term people's Angkola inangon psychologically disturbing to the wife of for the household, because her husband always asked his mother, or intervention of mother in law to couple.

This is affirmed by the following sentence: "8. without interfering of the third parties.9. I guess malo malo-Hamu Amang ... Parmaen. 10. I do not want to hear the problems of households to fit, if ... if necessary 11. Hu tu dokkon Hamu, hida Hamu Amang Boru kasi example Maen hate .. "Which means: 8. Do not interfere by a third party. 9. I think, you have to be very smart , my ... daughter. 10. I do not want to hear the problems of household (up anytime). 11. if ... if necessary, I say to you, follow our example, give examples daughter in law. The eighth sentence is clear that the third person is always making trouble on households, in the sentence it should be observed that the sentence 8. without interfering third parties.

Sentences that advice with a straightforward and firmly conveyed parents that fight in the household is the initial catastrophe in the family, therefore precaution not to quarrel, it is up to twice mentioned reinforced with the phrase, once again I say precaution. It reflects the characteristics of Luhak Angkola that are forthright in conveying something to the child and the in law.

\section{c. Mangupa that contains Life Advice to live peacefully as a family (Being in sakinah family) using concrete examples sentence in life.}


The use of sentences with a concrete example in the following sentence:. ."if... Hu dokkon tu Hamu, hida hamu Amang Boru... example hate Maen," means: if... if necessary, I say it to you, our example, give an example my daughter in law. In a concrete example sentences with "Hamu hida Amang Boru or see you guys (us), which means so emphatically parents of the bridegroom to the bride and groom to emulate their household.. It was also the sentence which emphasize the advice with concrete examples such as children now have a character that is not good as the second sentence: b) Ulang baen hamu songon daganak sannari, bayo matcari diligi anak boru i marcolak-colak tinggal di bagas manjojori tangga ni halak. Inda karejo on. c). Sabalikna ada boru matcari, diligi Bayo P6. Aha dei P6 on? Helter skelter pahae pahulu patidahon pieces. d). On karejo na bere on. Ingot on. Which means: b) Do not make you like a child now, working men, women just primp at home and a visit to the homes of people. That's not a job.

\subsection{Mangupa mingling with Relatives and Society}

The analysis of the text mangupa with the content of the sentence advices of the parents of the groom who aim to hang out and mingling can be proved as in the text of the sentence of advice such as: "Malo ma Ho, a black markoum na Bahat da, Hita on da Bahat on," which means: Get a grip on you guys, we have a family that much, we multiply this.

\subsection{Mangupa contents that devout to religion}

Angkola community known as religious people, obedience in observation religious will be reflected when the community and traditional leaders communicate for the ceremony. closing sentence which closed with the words horas ... just be spoken by the Raja Panusunan bulung as the cover of the traditions of indigenous mangupa Angkola. Similarly, in the sentence: "... and both greeting and salawat tu junjunganta great Prophet Muhammad Nahita haropkon sapaatna." What is interesting in shalawat sentence is to mix two languages, Arabic and Angkola (Tapanuli), namely: ... tu junjunganta ... which means: to our lord (great Prophet Prophet Muhammad SAW) na hita haropkon syafaatna, which means: that we expect his intercession. So, the Arabic usage and Angkola already become commonplace at the time expressed words of welcome, advice on customs Angkola mangupa ceremony. 


\subsection{Mangupa with a content to be given devouted children}

The sentence above advice delivered by ompung 1 (grandmother) expects offspring delivered with the sentence: "Hopefully received tondi dohot munu body, longevity ye na malo marpomparan. Songoni, Received tondi dohot body munu, Bahat rasoki markasehatan ma hita sude, parmaenku sude marsehat-sehat, so get ro pahomppu. "Which means: hopefully accepted the spirit and body of you, longevity you are very clever to give birth, accepted the spirit and your body.

We are all in good health, in order to quickly get grandchildren. In the sentence delivered by ompung 1 reflects the great expectations that have offspring delivered with the sentence: longevity ye na malo marpomparan, longevity guys and clever descendant (child / birth) it is reinforced by the second sentence: parmaenku sude marsehat-sehat, so get ro pahomppu, which means that everything is healthy so that immediately comes grandchildren. It is more appropriate sentence delivered by ompung and not the parent (mother or father) because it was considered impolite. Indeed, children as the fruit of love and affection of both parents, then to have a child for the community in Luhak Angkola it becomes a pride. Under these conditions, any traditional marriage ceremony is the highlight of the show is Angkola mangupa customary, are always advised to have a lot of children are 33 people consisting of 17 boys and 16 girls, it is known by the saying: "..., maranak Hamu sappulu pitu marboru sappulu Onom.

Although at odds with the government program through the National Population and Family Planning (BKKBN) (Indonesian Edition Now 4/1/8 July 2015: 10) that a continuing basis to encourage parents to family planning and implementing eight family functioning in everyday life namely the quality of a nation is determined by the quality of a family, so that all children quality is determined by the quality of the family. Therefore, the number of children as many as 33 people would need a little attention, let alone creating quality family, then a number of families with children 33 people is rare.

\subsection{Mangupa the contents to be diligent and hard working}

Mangupa text containing advice to diligent and to be hard working, delivered in a language that is more delicate because it is delivered in verses (berpantun), described by Raja 
Panusunan Bulung word of advice mentioned below: Idiama one ringgit three-eighths / a //, One month three thirty days / b //, Slightly similar edible / a //, If nobody is searched / b //. This means that quite a bit has a message for inviting and reminds the bride to be industrious and hard working. This was confirmed by the following words, namely: "... Young Adong bere, rap dipangan, nadong, rap dijalakan ..." which means that if any law (male) equally edible and if nothing is searched. So key words of advice delivered by Raja Panusunaeing Bulung it is being hard working.

Followed by the sentence of advice: "... beauty sigodang Manita nia. Napodo in food binoto dai na ma. sanga ahape Artina beauty siribu-thousand. Asa ombang mada hundred o mangaribu. Artina on, gogo ho mancari Opung, Maribu-thousand, marjuta-million, marmiliyar. Tai ho repeated corruption, KPK dikojar Naron. Halal na nai ma create Opung ate. "Which means: So is the rice that are here, it shows a sign of joy. not to mention we eat we already know it. Hopefully in the future more actively working for money thousands, millions even billions but do not do corruption.

\section{CONCLUSION}

Mangupa indigenous oral traditions of Angkola community is done with a set of materials to serve as a traditional narrative pangupa offers traditional atmosphere filled with the love of parents, relatives, traditional leaders, and indigenous peoples. Mangupa indigenous oral traditions of Angkola divided into: Ceremonial place, Current / time of the ceremony, objects and tools of the ceremony, leaders and participants of the ceremony. Mangupa ceremony types, and materials pangupa as an indicator that determines the size of mangupa ceremony. Oral tradition mangupa intends to seek blessings from Allah, the Almighty God to keep the couple safe, healthy, and prosperous, surviving / avoid danger, achievement of purpose. Mangupa advice sentences as in a family life from an indigenous community after analyzed and then grouped into eight parts consisting of: 1. Praise God the Almighty, 2) Prayer to married celebration 3) messages of harmonious and peaceful life (sakinah family), 4) mingle with relatives and society, 5) devoted to God, 6) Bless with pious children, 7) industrious and enterprising, 8) careful in 
using the money. The values of local wisdom in the sentences of advise of mangupa divided into: a) human relationship with the Creator. b) meaning of human life in interacting with relatives and communities, c) human relationship with nature e) advice to be industrious and enterprising, frugal, and to be religious, the pillars of peace (being a harmonious family), and aesthetic values of politeness, ethics, and showing respect in speaking.

\section{REFERENCES}

Amri, Yusni Khairul. 2011. Tradisi Lisan Upacara Perkawinan Adat Tapanuli Selatan: Pemahaman Leksikon Remaja di Padangsidimpuan. Tesis.

Avonina, Sthefaniny, 2006. "Apa yang dimaksud dengan Pengetahuan Tradisional?”,Konvergensi. Edisi IX, Oktober 2006.

Bascom, W.R, 1973. "Folklore, Verbal Art, and Culture". The Journal of American Folklore, Vol. 86, No. 342 (Oct.-Dec., 1973), pp. 374-381.

Eco. Umberto 1979. A Theory of Semiotics. Bloomington: Indiana University Press.

Foley, William A. 1997. Anthropological Linguistics: An Introduction. Oxford: Blackwell.

Foley, John Miles. (Ed) 1986. Oral Tradition in Literature: Interpretation in Context. Columbia: University of Missouri Press.

Finnegan, Ruth. 1992. Oral Traditions and The Verbal Arts: A Guide to Research Practices. New York: Routledge.

Harahap, Baginda Raja, Tanpa Tahun, "Poda-podda Ni Adat Horja Godang/ Bolon/ Siluluton/ Siriaon."

Hasil Musyawarah Lembaga Adat dan Budaya.24-26 Oktober 1996, ”Adat Budaya AngkolaSipirok-Haruaya Mardomu Bulung Napa-napa Ni Sibualbuali”.

Hoed. Benny H. 2008. Semiotik dan Dinamika Sosial Budaya. Depok: Fakultas Ilmu Pengetahuan Budaya Univesitas Indonesia.

Hutchby, I., Woofitt, R., 1994. Conversation Analysis. London:Polity Press.

Kluckhohn, C dan Strodttbeck. 1961. Variation in Values Orientation. Englewood Clifft. NJ.:Prentice-Hall. 
Ong, Walter J. 2007. Orality and Lteracy. New York: Methuen and Co. Ld.

Parsadaan Marga Harahap, 1993, Horja: Adat Istiadat Dalihan Natolu, Jakarta: Parsadaan Marga Harahap Dohot Anak Boruna.

Sibarani, Robert. 2012. Kearifan Lokal (Hakikat, Peran, dan Metode Tradisi Lisan). Jakarta: Asosiasi Tradisi Lisan (ATL).

Siregar Baumi, G. Gelar H. Sutan Tinggibarani, 1980, ’Horja Godang Magupa Di Na Haroan Boru”, (Naskah stensilan)

Siregar Baumi, G. Gelar H. Sutan Tinggibarani, 1984, "Surat Situmbaga Holing Adat BatakSipirok- Padang Bolak- Barumun- Mandailing- Batang Natal- Natal”, (Naskah stensilan)

Smith, W. Robertson. 1886-1894. Lecture on Religion of the Smites dalam Kuntjaraningrat. 1987. Sejarah teori Antropologi. Jilid I. Jakarta:UI Press.

Rahyono, F.X. 2009. Kearifan Budaya dalam Kata. Jakarta: Wedatama Widyasastra.

Lubis, M. Ridwan, 2013. “Tradisi dalam Kehidupan Berbudaya” Harian Waspada, Medan, 4 Juli 2013. 